\title{
The role of e-satisfaction, e-word of mouth and e-trust on repurchase intention of online shop
}

\author{
Wawan Prahiawan $^{a^{*}}$, Mochammad Fahlevi ${ }^{b}$, Juliana Juliana ${ }^{c}$, John Tampil Purba ${ }^{c}$ and Sri Apri- \\ anti Tarigan $^{\mathrm{d}}$
}

${ }^{a}$ Universitas Sultan Ageng Tirtayasa, Indonesia

${ }^{b}$ Management Department, BINUS Online Learning, Bina Nusantara University, Indonesia

${ }^{c}$ Universitas Pelita Harapan, Indonesia

${ }^{d}$ Institut Bisnis Informasi Teknologi dan Bisnis Medan, Indonesia

CH R O I C L E A B S T R A C T

Article history:

Received: June 8, 2021

Received in revised format: June

30, 2021

Accepted: August 21, 2021

Available online: August 21, 2021

Keywords:

E-Satisfaction

E-Word of Mouth

E-Trust

Repurchase Intention

Online Shop

\begin{abstract}
The purpose of this study was to analyze the relationship between E-Satisfaction, E-Word of Mouth and E-Trust on Repurchase Intention of Online Shop. The approach in the research used is a quantitative approach using PLS-SEM SmartPLS software as a data processing tool. In this study, the data collection technique was carried out using an online questionnaire which was distributed to 150 respondents' consumers of online shops. Sampling system with snowball sampling method. Based on the results of hypothesis testing, it was found that this study found that satisfaction had a positive and insignificant effect on repurchase intention. This shows that the e-satisfaction of online shop consumers does not significantly affect the repurchase intention of these consumers towards e-commerce online shops. In addition, e-word of mouth has a positive and insignificant effect on repurchase intention. This shows that the higher the e-word of mouth perceived by e-commerce consumers, the less significant customers will repurchase online. E-trust has a positive and significant effect on repurchase intention. This shows that the higher the e-trust perceived by online shop e-commerce consumers, the more customers will repurchase online. The novelty of this research is the new correlation model of e-satisfaction, e-word of mouth and e-Trust on repurchase intention of online shops and the research can be a reference for further research to be applied in other places or countries.
\end{abstract}

\section{Introduction}

In this digital era and industrial revolution, the increasing number of smart phones and cellular operators that provide internet services at low prices makes online business more fertile. According to Anser et al. (2021) many businesses are starting to use creative ways to promote their online stores. Starting from making artistic photos, interesting videos and other promotional content. Zainul (2019) and Zoghlami (2018) online business conditions in Indonesia are currently giving rise to an interesting phenomenon, namely the influence of influencers or celebrities who are getting stronger. Many online stores use their services to promote goods or services. Online shopping behavior has become a habit for many people, especially in the midst of the current pandemic. Moreover, Indonesia is the largest e-commerce market in Southeast Asia. According to Wearesocial and Hootsuite data, around $90 \%$ of internet users in Indonesia have shopped online. In 2019, the value of the e-commerce market capitalization in Indonesia reached USD 21 billion or around IDR 294 trillion (Ahmed \& Zahid, 2014). The e-commerce industry in Indonesia is predicted to reach a value of USD 40 billion by 2022 (Zainul, 2019; Zoghlami et al., 2018). There are

* Corresponding author.

E-mail address: wawan.prahyawan@ymail.com (W. Prahiawan)

(C) 2021 by the authors; licensee Growing Science, Canada. doi: $10.5267 /$ j.ijdns.2021.8.008 
several factors that influence the rapid development of e-commerce in Indonesia. One of the biggest factors is the rapid growth of the middle class in Indonesia, amounting to $25 \%$ of the total population or as many as 58.3 million people in 2021 . This is also seen by the increase in public spending on online consumer goods shopping by $26 \%$ in 2020 compared to 2019 . Apart from the increasing middle class, other factors that also support the development of e-commerce are the increasing level of internet penetration and mobile device users, allowing more people to access various online shopping platforms, starting from store websites online, marketplace applications and social media. Repurchase intention is customer satisfaction measured behaviorally by asking whether the customer will shop or use the company's services again. According to Ahmed and Zahid (2014) repurchase intention is defined as an individual's assessment of the repurchase of services or services from the same company by considering the current situation and the good atmosphere of the individual. In e-commerce applications, customer repurchase interest will appear after making a purchase accompanied by a feeling of satisfaction in shopping using the application. Research on electronic word of mouth conducted by Ahmed and Zahid (2014) shows that electronic word of mouth has a positive and significant effect on repurchase intention at Citilink Indonesia. Similar research on electronic word of mouth was conducted. Consumer commitment with the desire to make repeat purchases can be influenced by satisfaction from previous purchases. Satisfaction is a key factor that can affect repurchase intention. Andika et al. (2020) explained that high satisfaction from a service causes consumers to always consider repeat purchases. Satisfaction in using e-commerce applications is called electronic satisfaction or e-satisfaction. Basically, there is no significant difference between electronic (e-satisfaction) and traditional customer satisfaction. Ahmad et al. (2017) explained that e-satisfaction occurs when products and services exceed consumer expectations, the level of buyer satisfaction after comparing the purchase experience and perceived expectations with the post-purchase experience. Andika et al. (2020) showed that customer satisfaction has a positive and significant effect on repurchase intentions. Likewise, research conducted by Hasman et al. (2019) show that e-satisfaction has a positive and significant effect on repurchase intention. Trust has an important role in influencing the relationship between commitment and customer loyalty. E-commerce has a high potential risk from the transaction side, so that the factor of customer trust in vendors is a key factor in e-commerce. Andika et al. (2020) found that trust influences repurchase intention. Trust in an online site with e-trust is important because logically consumers have a higher level of risk perception than nononline transactions in terms of delivery, payment, and personal information (Yuliantoro et al., 2019).

According to Ahmad et al. (2017) e-satisfaction can be defined as a holistic evaluation of the relationship between website users and e-retailers. E-satisfaction occurs when products and services exceed customer expectations. This is the level of buyer satisfaction after comparing the purchase experience and perceived expectations with the post-purchase experience (Ebrahim, 2020). Satisfaction is a psychological condition that results when a customer is satisfied, and he/she is no longer looking for an alternative other than the website he/she was using at that time. When the customer is not satisfied, then he/she will look for other alternatives and it will be an opportunity for competitors to take advantage of the situation. Online shopping on marketplace sites does not allow for personal contact between prospective buyers and sellers (Faircloth et al., 2001). Consumers will only choose and consider purchasing products through images and information as stated on the website page only. The purchase will completely depend on the perception and trust of potential buyers on the site manager and the seller since one of the main foundations of online shopping is the level of consumer trust. The same thing was stated by others that customer trust in an online system (e-trust) is the main dimension of an online system. In interaction with an online shopping website, many studies have shown that e-trust or online trust is very important in online transactions. E-trust itself is defined as the basis for establishing relationships and maintaining relationships between customers and online sellers (Affandi et al., 2020). E-trust in E-retailers happens when customers are willing to accept vulnerabilities in online transactions based on positive expectations about future actions (Ebrahim, 2020). E-trust is a trust that consumers must buy via the internet. Reluctance to shop online can arise from uncertainty about settlement or perceived risks about payments and the security of personal information. Based on the above understanding, it can be concluded that e-trust or electronic trust is a trust that does not appear suddenly but must be built from the start. This trust will be a driving force in creating an effective relationship with customers (Nadaraja \& Yazdanifard, 2013). In general, word of mouth or WOM is a marketing communication tool that is incorporated in the promotion mix (Stephen, 2016; Wanasida, 2021). Marketing communication as a communication that aims to build awareness, increase consumer interest and interest in a product or brand which in turn can make consumers take action to purchase the brand (Faircloth et al., 2001). e-word of mouth is a positive or negative statement about a product or company made by potential customers, current and former customers, which is available to many people and institutions through the internet (Hellier et al., 2003). Repurchase intention is an individual's assessment of the repurchase of services or services from the same company by considering the current situation and the good atmosphere of the individual. According to Anser et al. (2021) repurchase intention can be defined as customer satisfaction measured behaviorally by asking whether the customer will shop or use the company's services again. Affandi et al. (2020) describes four indicators in identifying repurchase intentions, namely transactional interest, referential interest, preferential interest and exploratory interest. The purpose of this study was to analyze the relationship between E-Satisfaction, E-Word of Mouth and E-Trust on Repurchase Intention of Online Shop.

\section{Method}

The research method used is a quantitative approach. The data in the form of numbers are then processed and analyzed to obtain scientific information behind these numbers (Purwanto et al., 2021). In this study, the data obtained by SEM-PLS Software. This study used PLS-SEM because the model tested was the development of the previous research model (Asbari et al., 2021). Analyzing data with PLS-SEM can be done in two ways, namely the Measurement Model which is often called 
the Outer model and the Structural model called the Inner Model. In this study, the data collection technique was carried out using a questionnaire or online questionnaire which was distributed to 150 online shop consumer respondents. Sampling system with snowball sampling method.

\subsection{Validity test}

With the aim of knowing the validity or invalidity of the statement use in the questionnaire, the statement is declared valid if the statement used indicates something that will be measured (Latan et al., 2017). Validity testing focuses on all variables that have a unidimensional form. For this study, using convergent validity testing, namely through the Average variance extracted (AVE) value for each Latan et al. (2017). Validity of an indicator if the AVE value is equal to or more than 0.5

\subsection{Reliability Test}

To see the accuracy, and consistency of the model can be measured using the reliability test, in the SmartPLS 3.0 program there are two ways to test the instrument model, namely Cronbach's Alpha and Composite Reliability, but usually the results of Cronbach's Alpha test have a lower value, therefore Latan et al. (2017) recommend that reliability test be carried out using Composite Reliability. Latan et al. (2017) say that the assumption of accurate parameter estimates is tested using Composite Reliability, in Composite Reliability testing there is the use of the Rule of thumb to measure the reliability of a variable. Composite Reliability is said to be valid if the value is more than 0.7 (Purwanto et al., 2021).

\subsection{Structural Model Test}

This is used to calculate the significance value of the relationship between variables directly without mediation. In the SmartPLS 3.0 program to view the magnitude of the value of the relationship between variables can be seen in the Sample Mean table in the Path coefficients. To see the relationship between variables is significant or not. We can see in the TStatistics table where the value must be more than $>1.96$, or the P-Value (Betta) is less than $<0.05$ Latan, \& Noonan (2017).

\subsection{R Square (Coefficient of Determination Test)}

The correlation test uses the coefficient of determination $\left(\mathrm{R}^{2}\right)$ between the independent variable and the dependent variable with the aim of seeing whether there is a relationship between the Independent Variable and the Dependent Variable. The results of the coefficient of determination test $\left(\mathrm{R}^{2}\right)$ also show how much the independent variable explains the independent variable. An independent variable is said to contain the information needed by the dependent variable if it has an R-Square value of 1 (one) or at least close to it, and vice versa (Purwanto et al., 2021).

\subsection{Quality Index}

The test is to assess the model in an overall way. The test is to assess the model in an overall way. The Quality Index is measured by looking at the value of GoF (Goodness of fit), the better the resulting model can be seen from the higher the GoF value, GoF Small =0.10, GoF Medium =0.25, GoF Large 0.36 (Purwanto et al., 2021).

\subsection{Hypothesis testing}

According to Hair et al. (2019) after a research model is believed to be fit, a hypothesis test can be carried out. The next step is to test the hypothesis that has been built in this study. Hypothesis testing using the Bootstrapping function on SmartPLS 3.0. The hypothesis is accepted when the significance level is less than 0.05 or the t-value exceeds the critical value (Hair et al., 2014). The value of $\mathrm{t}$ statistics for the $5 \%$ significance level is 1.96 .

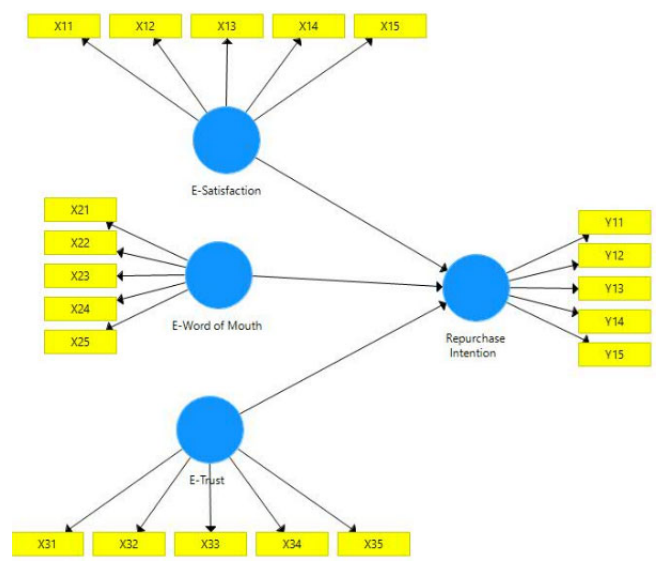

Fig 1. Research Model 
Hypothesis 1: There is a positive influence between E-Satisfaction on Repurchase Intention of Online Shop.

Hypothesis 2: There is a positive influence between E-Word of Mouth on Repurchase Intention of Online Shop.

Hypothesis 3: There is a positive influence between E-Trust on Repurchase Intention of Online Shop.

\section{Result and Discussion}

\subsection{Reliability test}

According to Hair et al. (2019), reliability is a measure of the internal consistency of indicators of a construct that shows the degree to which each of these indicators shows a general latent construct. According to Hair et al. (2019) the reliability requirement is a measure of the stability and consistency of the results at different times. To test the reliability of the construct in this study used the value of composite reliability. A variable is said to meet construct reliability if it has a composite reliability value $>0.7$ (Purwanto et al., 2019) and the Alpha Cronbach value $>0.7$ has a good level of reliability for a variable.

Table 1

Reliability Testing Result

\begin{tabular}{lcccc}
\hline & Cronbach's Alpha & rho_A & Composite Reliability & Average Variance Extracted (AVE) \\
\hline E-Satisfaction & 0.978 & 0.979 & 0.988 & 0.976 \\
E-Trust & 0.898 & 1.096 & 0.918 & 0.792 \\
E-Word of Mouth & 0.995 & 1.016 & 0.996 & 0.985 \\
Repurchase Intention & 0.988 & 0.994 & 0.992 & 0.977 \\
\hline
\end{tabular}

According to Table 1, it can be seen the results of the reliability test analysis using the SmartPLS tool which states that all composite reliability values are greater than 0.7 , which means that all variables are reliable and have met the test criteria. Furthermore, the value of Cronbach's omission also shows that all Cronbach's Alpha values are more than 0.6 and this indicates the level of reliability of the variable has also met the criteria.

\subsection{Convergent Validity}

Convergent validity is used to measure the correlation between item scores and construct scores, the higher the correlation the better the data validity (Purwanto et al., 2021). Measurement can be categorized as having convergent validity if the loading factor value is $>0.7$.

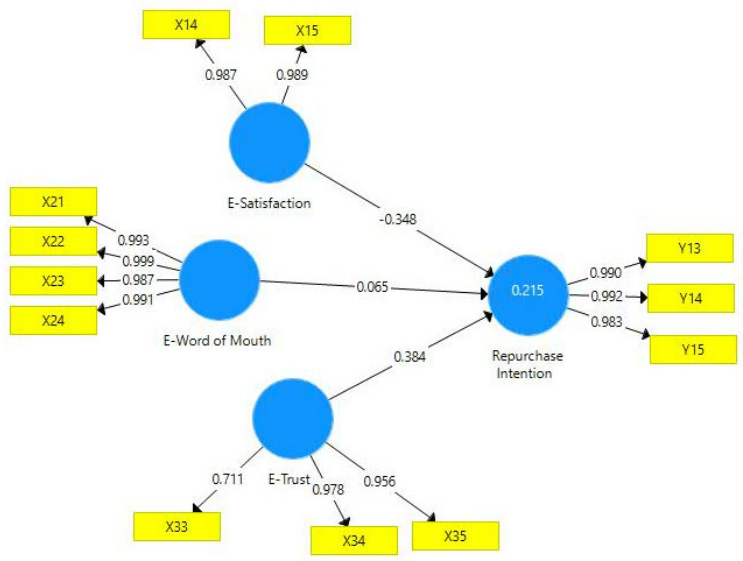

Fig. 2. Validity Testing

\subsection{Discriminant Validity}

Discriminant validity is a test of construct validity by predicting the size of the indicator from each block (Hair, 2019). One of the discriminant validities can be seen by comparing the AVE value with the correlation between other constructs in the model. If the AVE root value is $>0.50$, it means that discriminant validity is reached (Hair, 2018). Discriminant validity was also carried out based on the Fornell Larcker Criterion measurement with the construct. If the correlation of the constructs on each indicator is greater than the other constructs, it means that latent constructs can predict indicators better than other constructs (Purwanto et al., 2020). 
Table 2

Discriminant validity Result

\begin{tabular}{lllll}
\hline & E-Satisfaction & E-Trust & E-Word of Mouth & Repurchase Intention \\
\hline E-Satisfaction & 0.988 & & & \\
E-Trust & 0.703 & 0.890 & 0.993 & 0.988 \\
E-Word of Mouth & 0.405 & 0.407 & 0.676 & 0.564 \\
Repurchase Intention & 0.456 & & & 0.96 \\
\hline
\end{tabular}

Based on Table 2, it appears that each statement indicator has the highest loading factor value in the tested latent constructs than other latent constructs, meaning that each statement indicator can be predicted well by each latent construct in other words discriminant validity is valid.

\subsection{R Square Value}

The value of $\mathrm{R}$ square $\left(\mathrm{R}^{2}\right)$ is a measure of the proportion of the variation in the value of the affected variable which can be explained by the variable that influences it. If in a study using more than two independent variables, then the adjusted Rsquare (adjusted $R^{2}$ ) is used. The value of $r$ square adjusted is a value that is always smaller than $r$ square. The $R^{2}$ value is close to 1, with the limiting criteria being divided into 3 classifications, If the value of $\mathrm{R}^{2}=0.67 \mathrm{Model}$ is substance (strong), If the value of $\mathrm{R}^{2}=0.33$ the model is moderate (medium) and if the value of $\mathrm{R}^{2}=0.19$ the model is weak (bad)

Table 3

R Square Value

\begin{tabular}{lll}
\hline & R Square & R Square Adjusted \\
\hline Repurchase Intention & 0.215 & 0.187 \\
\hline
\end{tabular}

Based on table 3, the R Square of Repurchase Intention value is 0.187 or $18.7 \%$ means that the Repurchase Intention variable is influenced by the E-Satisfaction, E-Word of Mouth and E-Trust variable by $18.7 \%$, while the remaining $82.3 \%$ is influenced by other variables not discussed in this study.

\subsection{Hypothesis testing}

According to Hair et al. (2019) after a research model is believed to be fit, a hypothesis test can be carried out. The next step is to test the hypothesis that has been built in this study. In this case, the bootstrapping method is applied to the sample. Testing with bootstrapping is intended to minimize the problem of abnormal research data.

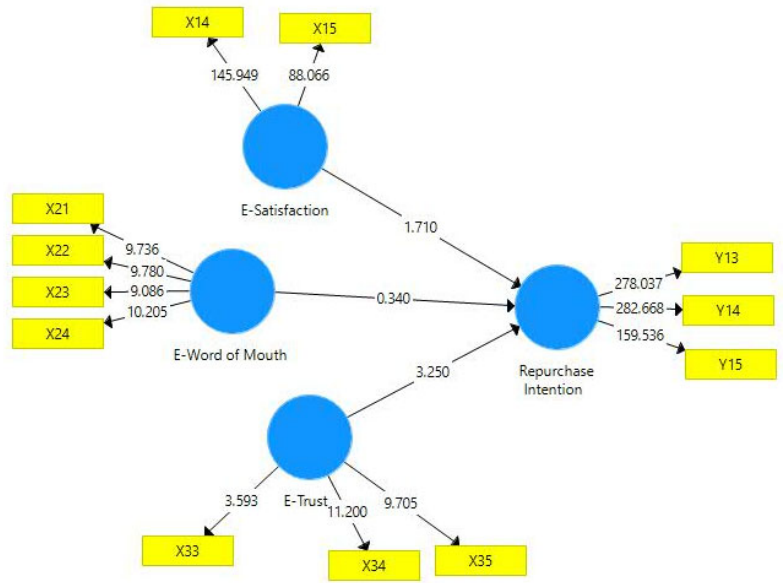

Fig. 3. Hypothesis Testing

The last step of the test using the Smart Pls application is hypothesis testing and is carried out by looking at the results of the bootstrapping value. Hypothesis testing using the Bootstrapping function on SmartPLS 3.0. The hypothesis is accepted when the significance level is less than 0.05 or the $t$-value exceeds the critical value (Hair et al., 2014). The value of $t$ statistics for the $5 \%$ significance level is 1.96 . 
Table 4

Hypothesis Testing

\begin{tabular}{ccccc} 
Correlation & Original Sample $(\mathrm{O})$ & T Statistics & P Values & Note \\
\hline E-Satisfaction $\rightarrow$ Repurchase Intention & 0.348 & 1.710 & 0.088 & Not Significant \\
E-Trust $\rightarrow$ Repurchase Intention & 0.384 & 3.250 & 0.001 & Significant \\
E-word of mouth $\rightarrow$ Repurchase Intention & 0.065 & 0.340 & 0.734 & Not Significant \\
\hline
\end{tabular}

\subsection{Effect of E-Satisfaction on Repurchase Intention}

Based on the results of the hypothesis testing, the original sample value was positive 0.348 and the $\mathrm{T}$ value was $1.710<1.96$ and $\mathrm{P}$ value $0.088>0.050$ so it was concluded that there was a positive but not significant relationship between E-Satisfaction and Repurchase Intention. This study found that satisfaction has a positive and insignificant effect on repurchase intention. This shows that the e-satisfaction felt by e-commerce online shop consumers will not significantly affect the e-repurchase intention of these consumers towards e-commerce online shops. Park and Oh (2012) stated that satisfaction increases future purchase intentions. In addition, the results of this study are not supported by research conducted by Pramono et al. (2021) and Salehnia et al. (2014) show that customer satisfaction has a positive and significant influence on purchase intention. Likewise, the research conducted by Wijaya et al. (2021) and Nagoya et al. (2021), who both conducted research on e-commerce, showed that e-satisfaction had a positive and significant effect on repurchase intention.

\subsection{Effect of E-Trust on Repurchase Intention}

Based on the results of the hypothesis testing, the original sample value was positive 0.384 and the $\mathrm{T}$ value was $3.250>1.96$ and $\mathrm{P}$ value $0.001<0.050$ so it was concluded that there was a positive and significant relationship between E-Trust and Repurchase Intention. This study found that e-trust has a positive and significant effect on repurchase intention. This shows that the higher the e-trust perceived by online shop e-commerce consumers, the more customers will repurchase online. The results of this study are supported by research from Park and Oh (2012) with the results that e-trust trust has a significant effect on repurchase intention at hotels in Lampung. Research conducted by Pramono et al. (2021) and Salehnia et al. (2014) shows that e-trust has a positive effect on online repurchase intention, which is indicated by a positive correlation coefficient. Susilo et al. (2020) and Rudyanto et al. (2020) in a study entitled the effect of consumer e-satisfaction and e-trust on online repurchase intention at Traveloka showed that e-trust has a positive and significant influence on online repurchase intention.

\subsection{Effect of E-Word of mouth on Repurchase Intention}

Based on the results of the hypothesis testing, the original sample value was positive 0.146 and the $\mathrm{T}$ value was $0.340<1.96$ and the $\mathrm{P}$ value was $0.340>0.050$ so it was concluded that there was an insignificant relationship between E-Word of mouth and Repurchase intention. This study found that e-word of mouth had a positive and insignificant effect on repurchase intention. This shows that the higher the e-word of mouth perceived by e-commerce consumers, the less significant customers will repurchase online. The results of this study are supported by Pramono et al. (2021) and Salehnia et al. (2014) who formulated that e-word of mouth has a significant effect on repurchase intention. Research conducted by Wijaya et al. (2021) and Nagoya et al. (2021) who found that the more positive the e-word of mouth, the higher the intention to repurchase.

E-satisfaction influences e-word of mouth. This shows that the e-satisfaction felt by online shop e-commerce consumers will affect the consumer's e-word of mouth towards the e-commerce online shop (Park et al., 2012). Respondents tend to recommend to others after respondents feel satisfied shopping. The higher the customer satisfaction, the greater the chances of the customer to recommend (Wijaya et al., 2021; Nagoya et al., 2021). E-trust influences e-word of mouth. This shows that the e-trust perceived by online shop e-commerce consumers will affect the consumer's e-word of mouth towards the e-commerce online shop. Customers tend to recommend to others after customers feel trust in the online shop. The higher the trust, the greater the chance for customers to recommend. E-satisfaction influences repurchase intention. This shows that the e-satisfaction felt by e-commerce online shop consumers will affect the e-repurchase intention of these consumers towards e-commerce online shops. Customers tend to repurchase on e-commerce, customers are satisfied with their online shopping. The higher the e-satisfaction, the greater the intention to repurchase. E-trust influences repurchase intention. This shows that the higher the e-trust perceived by online shop e-commerce consumers, the more customers will repurchase online (Stephen, 2016; Wanasida, 2021). Customers tend to repurchase on e-commerce when customers trust. So the higher the e-trust, the greater the intention to repurchase. E-word of mouth influences repurchase intention. This shows that the higher the e-word of mouth perceived by online shop e-commerce consumers, the more customers will repurchase online. Customers tend to repurchase in e-commerce when customers get e-word of mouth. So that the higher the e-word of mouth, the greater the intention to repurchase. E-satisfaction influences repurchase intention through e-word of mouth. This shows that e-word of mouth can strengthen and can also weaken consumer repurchase intentions at online shops, in this study e-word of mouth reduces the effect of e-satisfaction on repurchase intention (Susilo et al., 2020; Rudyanto et al., 2020). e-trust influences repurchase intention through e-word of mouth. This shows that e-word of mouth can strengthen and can also weaken repurchase intention of consumers at online shops, in the path analysis in this study e-word of mouth strengthens the influence of e-trust on repurchase intention of commerce Online shop consumers. 


\subsection{Practical Implications}

The practical implications of the research results for online shop companies show that E-Satisfaction has no effect on Repurchase Intention, E-Trust has an effect on Repurchase Intention and E-word of mouth has an effect on Repurchase Intention. Therefore, the online shop is considered necessary to consider each variable in this study. All elements within the company must be able to work together in improving a good brand image so that the product can be trusted by consumers. In terms of eWOM, it can be concluded that the internet or social media item is a place to express consumer dissatisfaction based on the survey results this item has the lowest value of the other items. So to increase sales of a product, the online shop adds support through a chat room system by customer service so that customers get a lot of information from customer service, online shops, and online shops will be consistent in their commitment to work together with their customers to satisfy their desires in realizing best product. Based on the conclusions that have been described regarding the results of the research, suggestions that can be given are, in using E-Word of Mouth as one of the promotional media carried out, Lazada must be able to increase interaction between users so that users are more interested in making E-Purchase Decisions at online shops. Furthermore, to keep E-Trust good in the eyes of consumers, the online shop must be able to make deliveries according to the time that has been set and there are no delays that will lead to disappointment. Then to increase consumer interest, online shops must update the Marketplace so that consumers will find it easier and faster to find the products they need.

\subsection{Theoretical Implications}

The theoretical implications of the three variables tested are E-satisfaction has no effect on repurchase intention, E-trust influences repurchase intention and E-word of mouth has no effect on repurchase intention. Only two variables that affect repurchase intention in online shops are E-Trust and E-word of mouth. From the results of this study, it can be said that it strengthens the theory which states that each of these two factors affects repurchase intention. However, because e-satisfaction does not affect repurchase intention, it can be said that e-satisfaction does not strengthen the theory which states that esatisfaction affects repurchase intention.

\section{Conclusion}

This study has found that satisfaction has a positive and insignificant effect on repurchase intention. This shows that the esatisfaction felt by e-commerce online shop consumers will not significantly affect the e-repurchase intention of these consumers towards e-commerce online shops. e-word of mouth has a positive and insignificant effect on repurchase intention. This shows that the higher the e-word of mouth perceived by e-commerce consumers, the less significant customers will repurchase online. e-trust has a positive and significant effect on repurchase intention. This shows that the higher the e-trust perceived by online shop e-commerce consumers, the more customers will repurchase online. This study has limitations, namely the limited number of respondents, the unit analysis is only on the online shop, so the results may not necessarily be applicable to other respondents and units of analysis. Suggestions for further research are increasing the number of respondents, using other sampling methods, adding other variables, and using other units of analysis.

\section{References}

Anser, M. K., Tabash, M. I., Nassani, A. A., Aldakhil, A. M., \& Yousaf, Z. (2021). Toward the e-loyalty of digital library users: investigating the role of e-service quality and e-trust in digital economy. Library Hi Tech.

Affandi, A., Sarwani, A. S., Erlangga, H., Siagian, A. O., Purwanto, A., Effendy, A. A., ... \& Juhaeri, G. (2020). Optimization of MSMEs Empowerment in Facing Competition in the Global Market during the COVID-19 Pandemic Time. Systematic Reviews in Pharmacy, 11(11), 1506-1515.

Ahmed, M. A., \& Zahid, Z. (2014). Role of social media marketing to enhance CRM and brand equity in terms of purchase intention. Asian Journal of Management Research, 4(3), 533-549.

Ahmad, A., Rahman, O., \& Khan, M. N. (2017). Exploring the role of website quality and hedonism in the formation of esatisfaction and e-loyalty: Evidence from internet users in India. Journal of Research in Interactive Marketing, 11(3), 246267.

Andika, Bernarto, Purwanto. (2020). How to Achieve Value Creation in Digital World? The Influence of IT Response on Value Creation and Customer Satisfaction. International Journal of Advanced Science and Technology, 29(3), 6705 6715.

Ebrahim, R. S. (2020). The role of trust in understanding the impact of social media marketing on brand equity and brand loyalty. Journal of Relationship Marketing, 19(4), 287-308.

Faircloth, J. B., Capella, L. M., \& Alford, B. L. (2001). The effect of brand attitude and brand image on brand equity. Journal of Marketing Theory and Practice, 9(3), 61-75.

Hair Jr, J. F., Hult, G. T. M., Ringle, C. M., \& Sarstedt, M. (2021). A primer on partial least squares structural equation modeling (PLS-SEM). Sage publications.

Hair, J. F., Risher, J. J., Sarstedt, M., \& Ringle, C. M. (2019). When to use and how to report the results of PLS-SEM. European business review. 
Hellier, P. K., Geursen, G. M., Carr, R. A., \& Rickard, J. A. (2003). Customer repurchase intention: A general structural equation model. European Journal of Marketing, 37(11/12), 1762-1800.

Latan, H., Noonan, R., \& Matthews, L. (2017). Partial least squares path modeling. Partial least squares path modeling: basic concepts, methodological issues and applications. https://oi. org/10.1007/978-3-319-64069-3 DOI: https://doi. org/10.1007/978-3-319-64069, 3.

MUNAWAROH, M., SANTOSO, B., GUMILANG, R. R., HIDAYATULLAH, D., HERMAWAN, A., MARHANAH, S., \& PURWANTO, A. (2021). The Effect of Strategic Leadership and Organization Culture on Business Performance: An Empirical Study in Indonesia. The Journal of Asian Finance, Economics and Business, 8(6), 455-463.

Nadaraja, R., \& Yazdanifard, R. (2013). Social media marketing: advantages and disadvantages. Center of Southern New Hempshire University, 1-10.

Pramono, R., Djakasaputra, A., \& Bernarto, I. (2020). Observational Learning and Word of Mouth Against Consumer Online Purchase Decision during the Pandemic COVID-19. System Review Pharmacy 11(9), 751-758.

Park, J., \& Oh, I. K. (2012). A case study of social media marketing by travel agency: The salience of social media marketing in the tourism industry. International Journal of Tourism Sciences, 12(1), 93-106.

PRAMONO, R., Sondakh, L. W., BERNARTO, I., JULIANA, J., \& PURWANTO, A. (2021). Determinants of the small and medium enterprises progress: A case study of SME entrepreneurs in Manado, Indonesia. The Journal of Asian Finance, Economics, and Business, 8(1), 881-889.

Purwanto, A., Asbari, M., \& Santoso, T. (2021). Education Management Research Data Analysis: Comparison of Results between Lisrel, Tetrad, GSCA, Amos, SmartPLS, WarpPLS, and SPSS For Small Samples. Nidhomul Haq : Jurnal Manajemen Pendidikan Islam, 6(2), 382-399. https://doi.org/10.31538/ndh.v6i2.1575

Purwanto, A., Asbari, M., Santoso, T. I., Paramarta, V., \& Sunarsi, D. (2020). Social and Management Research Quantitative Analysis for Medium Sample: Comparing of Lisrel, Tetrad, GSCA, Amos, SmartPLS, WarpPLS, and SPSS. Jurnal Ilmiah Ilmu Administrasi Publik, 10(2), 518-532.

Purwanto, A., Asbari, M., Santoso, T. I., \& Haque, M. G. (2019). Marketing Research Quantitative Analysis for Large Sample: Comparing of Lisrel, Tetrad, GSCA, Amos, SmartPLS, WarpPLS, and SPSS. Jurnal Ilmiah Ilmu Administrasi Publik, 9(2), 355-372.

Purwanto, A., Asbari, M., Santoso, T. I., Sunarsi, D., \& Ilham, D. (2021). Education Research Quantitative Analysis for Little Respondents. Jurnal Studi Guru Dan Pembelajaran, 4(2), 335-350.

Nagoya, R., Bernarto, I., Antonio, F., Pramono, R., Wanasida, A. S., \& Purwanto, A. (2021). Exploring Intention to Enroll University Using an Extended Stimulus-organism-response Model. Academy of Strategic Management Journal, $20,1-12$.

Salehnia, M., Saki, M., Eshaghi, A., \& Salehnia, N. (2014, April). A Model of E-Loyalty and Word-Of-Mouth based on etrust in E-banking services (Case Study: Mellat Bank). In 8th International Conference on e-Commerce in Developing Countries: With Focus on e-Trust (pp. 1-7). IEEE.

Susilo, R., Bernarto, I., \& Purwanto, A. (2020). Effect of trust, value and atmosphere towards patient satisfaction (case study on preama clay of wae laku, indonesia). International Journal of Advanced Science and Technology, 29(3), 6716-6723.

Rudyanto, R., Soemarni, L., Pramono, R., \& Purwanto, A. (2020). The influence of antecedents of supply chain integration on company performance. Uncertain Supply Chain Management, 8(4), 865-874.

Stephen, A. T. (2016). The role of digital and social media marketing in consumer behavior. Current opinión in Psychology, 10, 17-21.

WANASIDA, A. S., BERNARTO, I., SUDIBJO, N., \& PURWANTO, A. (2021). The Role of Business Capabilities in Supporting Organization Agility and Performance During the COVID-19 Pandemic: An Empirical Study in Indonesia. The Journal of Asian Finance, Economics and Business, 8(5), 897-911. https://doi.org/10.13106/JAFEB.2021.VOL8.NO5.0897

Wijayaa, O., Sulistiyanib, S., Pudjowatic, J., Kurniasih, N., \& Purwanto, A. (2021). The role of social media marketing, entertainment, customization, trendiness, interaction and word-of-mouth on purchase intention: An empirical study from Indonesian smartphone consumers. International Journal of Data and Network Science, 5(3), 231-238.

Yuliantoro, N., Goeltom, V., Juliana, I. B., Pramono, R., \& Purwanto, A. (2019). Repurchase intention and word of mouth factors in the millennial generation against various brands of Boba drinks during the Covid 19 pandemic. African Journal of Hospitality, Tourism and Leisure, 8(2), 1-11.

Zainul, A. (2019). The Influence of E-service Quality toward E-satisfaction, E-trust, E-word of Mouth and Online Repurchase Intention: A Study on the Consumers of the Three-star Hotels in Lampung. Russian Journal of Agricultural and SocioEconomic Sciences, 93(9).

Zoghlami, A. T., Yahia, K. B., \& Berraies, S. (2018). From mobile service quality evaluation to e-word-of-mouth: what makes the users of mobile banking applications speak about the bank?: The moderating role of brand reputation. International Journal of E-Services and Mobile Applications (IJESMA), 10(2), 36-57.

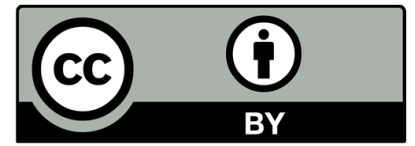

(C) 2021 by the authors; licensee Growing Science, Canada. This is an open access article distributed under the terms and conditions of the Creative Commons Attribution (CC-BY) license (http://creativecommons.org/licenses/by/4.0/). 